\title{
COVID-19 AND NUTRITION
}

\section{COVID-19 and nutrition}

O. Krekhovska-Lepiavko, B. Lokay, S. Yastremska, N. Reha, O. Bushtynska, S. Danchak

I. Horbachevsky Tenopil National Medical University

e-mail: lepyavkoom@tdmu.edu.ua

Summary. Currently Covid-19 pandemic is a leading challenge across the globe. It is mandatory to attain and maintain good nutritional status to fight against virus. Nutritional status of individual is affected by several factors such as age, sex, health status, life style and medications. Nutritional status of individuals has been used as resilience towards destabilization during this COVID-19 pandemic. Optimal nutrition and dietary nutrient intake impact the immune system, therefore the only sustainable way to survive in current context is to strengthen the immune system. There is no evidence found that supplement can cure the immune system except Vit $C$, which is one of the best way to improve immune system. A proper diet can ensure that the body is in proper state to defeat the virus. However along with the dietary management guidelines the food safety management and good food practices is compulsory. This article explores the importance of nutrition to boost immunity and gives some professional and authentic dietary guidelines about nutrition and food safety to withstand COVID-19.

The aim of the study - to analyze and systematize the literature data about the influence of nutrition on the manifestation of COVID-19 infection.

Materials and Methods. The study uses publications of the world scientific literature on COVID-19 infection, in particular the causes and mechanisms of its development, treatment, complications and its consequences as well as the influence of different nutrients and nutrasuticals on the course of COVID-19. This review highlights the nutritional interventions to increase the immune response in the body during viral infections, especially considering the novel coronavirus pandemic. Due to their beneficial effects on general healthcare and disease prophylaxis, nutraceuticals have been gaining more and more importance lately.

Results. During the COVID-19 pandemic, the nutritional status of individuals has been used as a measure of resilience toward destabilization. Optimal nutrition and dietary nutrient intake impact the immune system through gene expression, cell activation, and signaling molecules modification. In addition, various dietary ingredients are determinants of gut microbial composition and subsequently shape the immune responses in the body. Therefore the existing evidence suggests that the only sustainable way to survive in the current situation is to strengthen the immune system. An adequate intake of zinc, iron, and vitamins $A, B$ $12, B 6, C$, and $E$ is essential for the maintenance of immune (c)O. Krekhovska-Lepiavko et al., 2021

\section{Вплив харчування на перебіг COVID-19}

О. Креховська-Лепявко, Б. Локай, С. Ястремська, Н. Рега, О. Буштинська, С. Даньчак

Тенопільський національний медичний університет імені І. Я. Горбачевського МОЗ України

Резюме. На сьогодні пандемія COVID-19 являє собою виклик для усього світу. Для боротьби з вірусом обов'язковим $є$ досягнення та підтримка належного харчового статусу. Загальновідомо, що на харчовий статус людини впливає цілий ряд фракторів, таких, як вік, стать, стан здоров'я, спосіб життя та приймання лікарських засобів. Належний харчовий статус сприяв підвищенню стійкості та опірності організму людини до вірусного навантаження під час пандемії COVID-19. Оптимальне харчування та споживання поживних речовин позитивно впливають на імунну систему, тому одним із дієвих методів запобігання інфрікуванню COVID-19 в сучасних умовах є зміцнення імунної системи. На сьогодні не знайдено жодних доказів того, що харчування може являти собою один із методів лікування уражень імунної системи (окрім даних про позитивний вплив вітаміну С, який вважається одним з найкращих засобів, які підвищують специфрічну і неспецифрічну резистентність організму). Правильна дієта може забезпечити підтримання належного стану організму людини для боротьби з вірусними ураженнями. В даній статті проаналізовано важливість харчування для підвищення імунітету та наведено деякі рекомендації щодо оптимального харчування для протистояння COVID-19.

Мета дослідження - проаналізувати та систематизувати літературні дані про вплив харчування на прояви інфрекції COVID-19.

Матеріали і методи. У дослідженні використані публікації світової наукової літератури про інфекцію COVID-19, зокрема про причини та механізми їі розвитку, лікування, ускладнення та її наслідки, а також вплив харчування на перебіг COVID-19. Даний огляд розкриває роль харчовання у підсиленні імунної відповіді організму під час вірусних інфекцій, особливо враховуючи наявність нової пандемії коронавірусу.

Результати. Під час пандемії COVID-19 харчовий статус людей має особливо важливе значення. Оптимальне харчування та дієтичне споживання поживних речовин впливають на імунну систему завдяки експресії генів, активації клітин та модифрікації сигнальних молекул. Крім того, різні дієтичні інгредієнти $є$ детермінантами мікробного складу кишечника і згодом формують імунні реакції в організмі. Адекватне споживання цинку, заліза та вітамінів $A, B_{12}, B_{6}$, C ma $E$ має 
function. In the current scenario, COVID-19 has imposed a new set of challenges for the individual to maintain a healthy diet. The state of self-isolation, lockdown, and social distancing are important measures to flattening the curve of the disease, although these measures have severe repercussions on an individual's life. The act of confining to one's home has significant impacts on one's health, including changes in eating patterns, sleeping habits, and physical activity. It would promote sedentary behaviors that affect mental and physical health and lead to an increased risk of obesity. Fear and anxiety may also cause changes in dietary habits leading to unhealthy dietary patterns and less desire to eat or with lessened enjoyment during eating. Micronutrients are dietary components that may contribute substantially to a robust immune system. Essential micronutrients like vitamins $A, D, E, C, B_{6}, B_{12}$, and folate and trace elements such as iron, zinc, and selenium, available in a variety of fresh animal- and plant-based foods, aid the body's ability to fight infections.

Conclusions. COVID-19 became the most challenging pandemic influencing all countries worldwide. A proper and healthy diet can ensure a robust immune system that can resist any onslaught by the virus. A certain amount of particular nutrient saturates into cells and prevents any kind of nutritional deficiency. Individuals consuming well-balanced diets appear to be safer with better immune systems and lower incidence of chronic diseases and infections.

Key words: COVID-19; viral infection; nutrition; chronic disorders.

\section{INTRODUCTION}

COVID-19 pandemic is posing severe threats to international health and the economy.

- At the moment there is still no cure for the disease

- Alternative methods need to be found to control the spread of the virus [1].

COVID-19 is caused by specific Coronavirus (SARS-CoV 2). Coronaviruses primarily cause enzootic infections in animals but is capable of transferring to humans and causing infections eg.: 2002

- Severe Acute Respiratory Syndrome (SARS) in

- Middle East Respiratory Syndrome (MERS) in 2012.

- Both Zoonotic Diseases

The outbreaks of SARS, MERS and COVID-19 demonstrate how lethal Coronaviruses can be when they cross the species barrier and infect humans [2]. Interestingly, the genome structure of COVID-19 is $82 \%$ identical to that of the SARS- CoV genome [3]. Lessons learned from the SARS (2002) outbreak could be applied or tried to apply to COVID-19.

Symptoms of COVID-19 include:

- Fever, cough, respiratory symptoms, shortness of breath, breathing difficulties, fatigue and a sore throat.

- A minority group of people will present with more severe symptoms and will need to be hospitalised, важливе значення для підтримки належного функціонування імунної системи. Необхідність у самоізолячії та дотримання соціальної дистаниії є невід'ємними заходами в рамках пандемії COVID-19, проте вони мають серйозні наслідки для життя людини і приводять до зміни режиму харчування, сну та фрізичної активності. Це сприяє розвитку малорухомої поведінки людей, яка впливає на психічне та фрізичне здоров'я та веде до підвищення ризику ожиріння. Страх і занепокоєння можуть також спричинити зміни в харчових звичках, що веде до нездорового режиму харчування та зниження апетиту або зменшення задоволення від їжі. Мікроелементи - це дієтичні компоненти, які можуть суттєво сприяти зміцненню імунної системи. Такі важливі мікроелементи, як вітаміни $A, D, E, C, B_{6}, B_{12}$, а також фолати та мікроелементи, такі, як залізо, цинк та селен доступні у різноманітних свіжих продуктах тваринного та рослинного походження, допомагають організму в боротьбі з інсрекційними захворюваннями.

Висновки. COVID-19 став найскладнішою пандемією, яка на сьогоднішні має виражений вплив на усі країни світу. Правильне та здорове харчування може забезпечити надійне та стійке фрункціонування імунної системи для боротьби з вірусом. У даний час доведено, що люди, які дотримуються збалансованої дієти, менш схильні до розвитку різноманітних хронічних захворювань та інфекцій.

Ключові слова: COVID-19; вірусна інфекція; хронічні розлади.

most often with pneumonia, and in some instances, the illness can include ARDS, sepsis and septic shock [4].

\section{Nutrition}

1. Not a cure for COVID-19 but healthy patterns of eating optimize the function of the immune system, improve immunometabolism, and are a modifiable contributor to the development of chronic disease that is highly associated with COVID-19 deaths.

2. May have a positive impact on COVID-19 as it may be a way to support people at higher risk for the disease i.e. older people and people with pre-existing conditions (non-communicable diseases).

The aim of the study - to analyze and systematize the literature data about the influence of nutrition on the manifestation of COVID-19 infection.

\section{MATERIALS AND METHODS}

The study uses publications of the world scientific literature on COVID-19 infection, in particular the causes and mechanisms of its development, treatment, complications and its consequences as well as the influence of different nutrients and nutrasuticals on the course of COVID-19. This review highlights the nutritional interventions to increase the immune response in the body during viral infections, especially considering the novel coronavirus pandemic. Due to 
their beneficial effects on general healthcare and disease prophylaxis, nutraceuticals have been gaining more and more importance lately.

\section{RESULTS AND DISCUSSION}

Symptoms and Risk Factors of COVID-19

Two to 14 days after exposure to the virus, the usual clinical signs are dry cough and shortness of breath. The Centers for Disease Control and Prevention (CDC) reported that the appearance of fever, chills, myalgia, headache, as well as the loss of smell and taste, could indicate an infection. The majority of humans have mild symptoms if any occur, and it has been reported that ca. $80 \%$ of infected people do not need hospitalization [4].

Nevertheless, in some individuals, the infection can cause severe problems. With aging, the immune response becomes weaker (immunosenescence), and the levels of inflammatory mediators in the blood increases (inflammageing). The high-risk group of COVID-19 that are clinically vulnerable includes primarily elderly individuals and those with inflammationassociated conditions such as overweight and obesity, chronic obstructive pulmonary disease, cardiovascular diseases, diabetes, kidney disease, etc. The majority of severe COVID-19 cases and mortalities were within the abovementioned group of individuals, although it is worrisome that younger and healthy individuals are showing up in this cohort $[5,6]$.

The virus rapidly multiplies and infects the surrounding cells throughout the respiratory system. At the time the virus gets to the lungs, an inflammatory process starts in the mucous membranes and damages the alveoli, which have difficulties in supplying oxygen, resulting in breathing difficulties. This can cause swelling in the lungs, which can result in the accumulation of fluids and dead cells and, finally, severe pneumonia. The infection can spread through mucous membranes of the body, such as the digestive system. In some cases, gastrointestinal symptoms like diarrhea, indigestion, and vomiting have been reported along with respiratory symptoms, and studies propose the possibility of fecal-oral transmission [7]. The typical symptoms of COVID-19 and their incidence percentage in 55,924 laboratory confirmed cases are illustrated in Figure 1 (according to the report of the WHO-China Joint Mission; 20 Feb., 2020).

SARS-CoV-2 has been isolated from the brainstems of positive patients, which indicates that this virus has common pathways of transmission with other coronaviruses that can spread through synapseconnected routes from the lung and airways. The virus can cause problems in different parts of the body, such as the heart, liver, and kidneys, particularly in the later stage of the disease. Fatal cases of COVID-19 can be caused by multiple organ failure, especially in individuals with genetic immune factors $[8,9]$.

This review highlights the nutritional interventions to increase the immune response in the body during viral infections, especially considering the novel coronavirus pandemic. Due to their beneficial effects on general healthcare and disease prophylaxis, nutraceuticals have been gaining more and more importance lately [10].

World Health Organisation: Nutrition Advice during the COVID-19 outbreak. Good nutrition and hydration are important. A well-balanced diet keeps you healthy, strengthens the immune system, and reduces the risk of chronic disease and infectious disease. It is recommended that a diet with a variety of fresh food and unprocessed foods is followed daily, to provide the body with the necessary vitamins, minerals, dietary fibre, protein, and antioxidants [11].

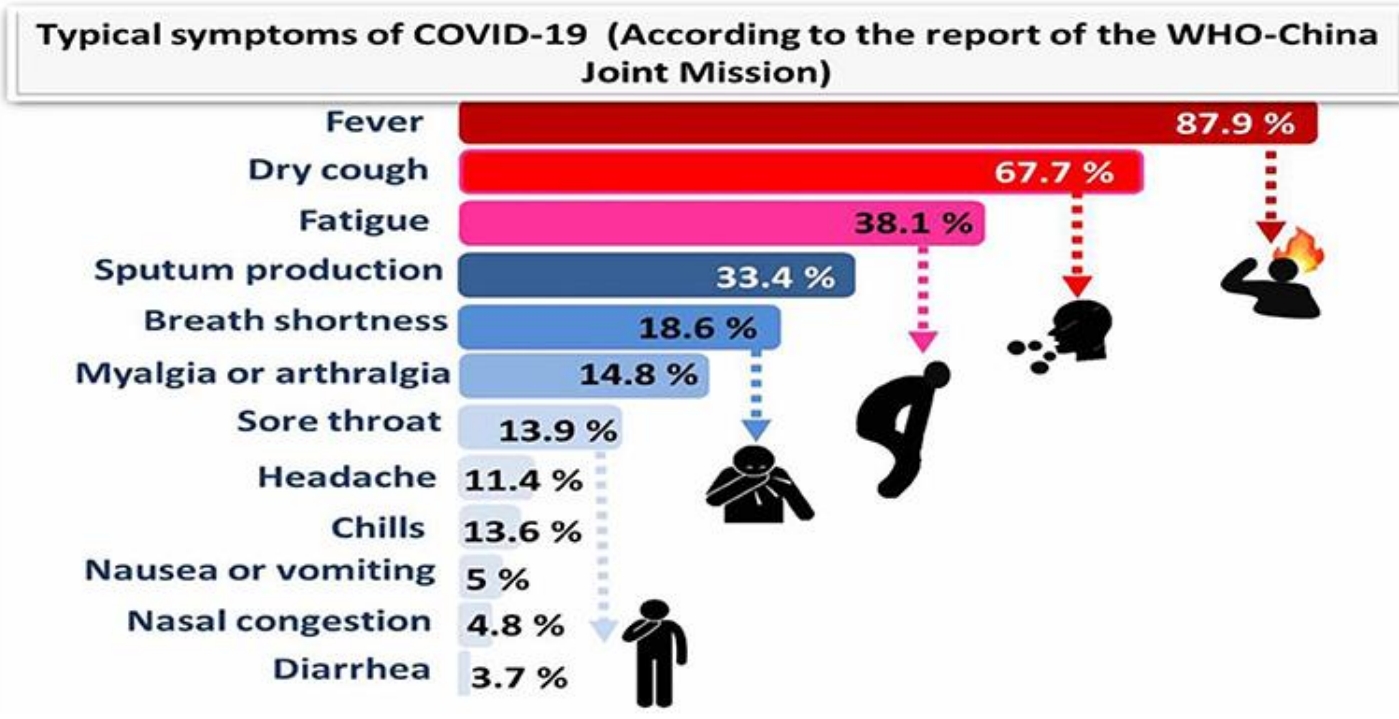

Figure 1. Typical symptoms of COVID-19 (according to the report of the WHO-China Joint Mission) relied on 55,924 COVID-19 confirmed cases (February 2020). 
Eat fresh and unprocessed foods every day

- Include fruits, vegetables, legumes, nuts and whole grains and foods from animal sources (e.g. meat, fish, etc)

- Daily portion recommendations:

- 2 cups of fruit (4 servings)

- 2.5 cups of vegetables (5 servings)

- $180 \mathrm{~g}$ grains

- $160 \mathrm{~g}$ meat and beans (red meat 1-2 times/ week and poultry or fish 2-3 times/week)

- Snack on raw vegetables and fruit, rather than foods that are high in sugar, fat or salt

- Avoid overcooking vegetables and fruit - to avoid the loss of important vitamins

- If using canned fruit or vegetables - choose wisely, avoid varieties with added salt and sugar

- Drink enough water every day

- Water is essential

- It transports nutrients and compounds in blood, regulates body temperature, gets rid of waste and lubricates and cushions joints

- Drink 8-10 cups of water daily

- Water is the best choice, other drinks can also be consumed such as lemon juice (diluted in water and unsweetened), tea and coffee. Avoid consuming too much caffeine, sweetened fruit juices, fizzy drinks and drinks high in sugar

- Eat moderate amounts of fat and oil

- Eat unsaturated fats rather than saturated fats

- Choose meat that is low in fat

- Avoid processed meats as it is high in salt and fat

- Avoid industrially produced trans fat - fast food, fried food, etc

- Eat less salt and sugar

-When cooking and preparing food, limit the amount of salt

- Limit daily salt intake to less than $5 \mathrm{~g}$ (1 teaspoon)

- Avoid foods high in salt and sugar

- Limit intake of soft drinks and sodas that are high in sugar

- Choose fresh fruits instead of sweet snacks such as cookies, cake and chocolate

Immune Boosting Foods

A healthy immune system can defeat invading pathogens. Many products on store shelves claim to boost or support immunity. But the concept of boosting immunity actually makes little sense scientifically. In fact, boosting the number of cells in your body - immune cells or others - is not necessarily a good thing. For example, athletes who engage in "blood doping" - pumping blood into their systems to boost their number of blood cells and enhance their performance - run the risk of strokes.

- Attempting to boost the cells of your immune system is especially complicated because there are so many different kinds of cells in the immune system that respond to so many different microbes in so many ways. Which cells should you boost, and to what number? So far, scientists do not know the answer. What is known is that the body is continually generating immune cells. Certainly, it produces many more lymphocytes than it can possibly use. The extra cells remove themselves through a natural process of cell death called apoptosis - some before they see any action, some after the battle is won. No one knows how many cells or what the best mix of cells the immune system needs to function at its optimum level.

- There is some evidence that various micronutrient deficiencies - for example, deficiencies of zinc, selenium, iron, copper, folic acid, and vitamins A, B6, $C$, and $E$ - alter immune responses in animals, as measured in the test tube.

Nutrition and immune defense

Micronutrients are dietary components that may contribute substantially to a robust immune system [12]. Essential micronutrients like vitamins A, D, E, C, $B_{6}, B_{12}$, and folate and trace elements such as iron, zinc, and selenium, available in a variety of fresh animal- and plant-based foods, aid the body's ability to fight infections $[13,14]$. Health and survival are increasingly dependent on the functioning of the immune system. Mechanistically, a rapid innate immune response occurs through phagocytes when a pathogen assaults the living system, but an adaptive immune response more specifically identifies the invading pathogen. Basically, these immune responses are controlled and coordinated by $T$ cells, which recognize the antigens and are classified as cytotoxic $T$ cells. Cytotoxic $T$ cells kill infected, damaged cells and the $T$ helper cells Th1 and Th2. These cells are involved in antiviral and cellular immune responses as well as humoral and antiparasitic responses [15]. A strong immune system ensures host defense against pathogens and neoplastic cells, and balanced nutrition augments the immune system to provide optimal defense against infectious agents. Many scientists have explained the critical role of the immune system as well as the defense mechanisms involved in protecting the body from invading agents, particularly in the presence of appropriate nutrition. A lot of them reported their findings on the kinetics of the immune response to COVID-19, describing higher concentrations of follicular helper T cells, antibody-secreting cells, activated $\mathrm{CD}^{+}$and $\mathrm{CD}^{+} \mathrm{T}$ cells, and immunoglobulin $\mathrm{M}$ (IgM) and immunoglobulin G (IgG) antibodies, all of which were observed to bind to coronavirus SARS-CoV-2. The results thus validate the role of a strong immune defense in patients COVID-19.

An optimally functioning immune system is closely linked to an adequate supply of micronutrients to the body, while severe deficiencies of these micronutrients 
lead to weakened immune responses and vulnerability to infections. Vitamins A, C, E, and B complex, along with folic acid, zinc, selenium, iron, and copper, all play important roles in boosting the immune system of the population $[16,17]$. Several studies have confirmed that micronutrient deficiencies are associated with a weakened immune system that predisposes individuals to increased vulnerability to infections $[18,19]$. It was demonstrated the critical role of essential vitamins and trace elements in boosting the immune system. They emphasized that micronutrients such as vitamins $A, B_{6}, B_{12}, C$,
$D$, and $E$, (Figure 2) in addition to iron, selenium, and zinc (Table 1), [20-30] might work synergistically to help immune cells function appropriately.

Recent research also supports a role of certain minerals and vitamins as adjunct therapeutic agents to treat microbiological infections as well as immunological and nonimmunological chronic diseases [31-39].

More recently, it was reviewed the association between optimal nutrition and the immune system in providing better protection against viral infections. Scientists suggested that essential micronutrients and

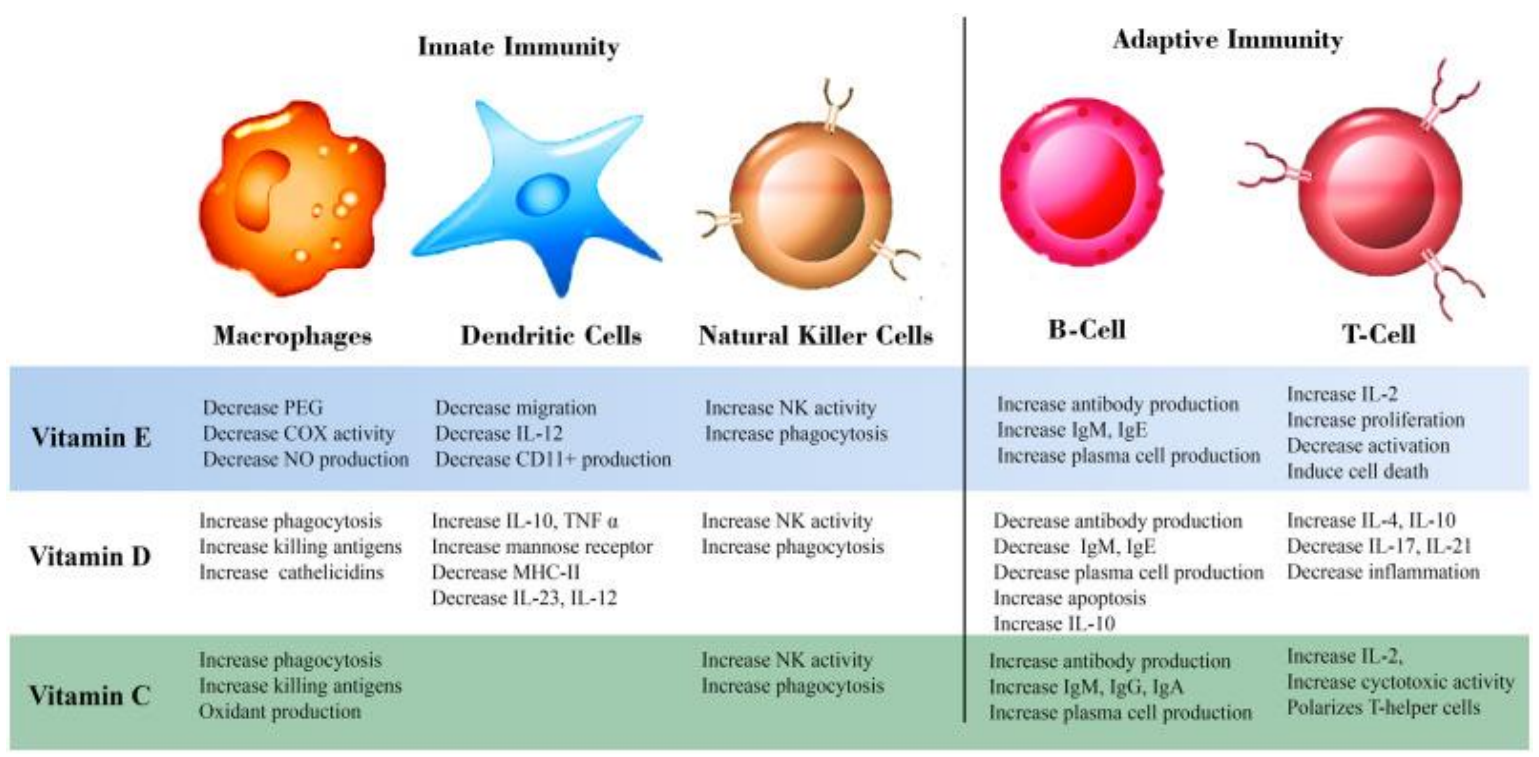

Figure 2. Role of vitamins $\mathrm{E}, \mathrm{D}$, and $\mathrm{C}$ in innate and adaptive immunity. Abbreviations: COX, cyclooxygenase; Ig, immunoglobulin; IL, interleukin; MHC, macrophage histocompatibility complex; NK, natural killer; NO, nitric oxide; PEG, polyethylene glycol; TNF, tumor necrosis factor.

Table 1. Role of selected minerals in innate and adaptive immunity

\begin{tabular}{|c|c|c|}
\hline Mineral & Role in innate immunity & Role in adaptive immunity \\
\hline Folate & $\begin{array}{l}\text { - Supports innate immunity } \\
\text { - Increases production of NK cells }\end{array}$ & $\begin{array}{l}\text { - Improves cell-mediated immunity } \\
\text { - Increases expression of antigen-presenting } \\
\text { cells } \\
\text { - Increases antibody-mediated immune } \\
\text { response } \\
\text { - Increases antibody production } \\
\text { - Assists T-helper cell-mediated immune } \\
\text { response }\end{array}$ \\
\hline Iron & $\begin{array}{l}\text { - Regulates production of cytokines } \\
\text { - Improves phagocytosis }\end{array}$ & $\begin{array}{l}\text { - Increases T-cell proliferation } \\
\text { - Improves cytotoxic T-cell function }\end{array}$ \\
\hline Zinc & $\begin{array}{l}\text { - Protects cells from oxidants } \\
\text { - Helps maintain skin and mucosal cell membrane } \\
\text { integrity }\end{array}$ & $\begin{array}{l}\text { - Promotes release of cytokines to mediate } \\
\text { adaptive immunity } \\
\text { - Assists T-helper } 1 \text { cells } \\
\text { - Activates T cells }\end{array}$ \\
\hline Copper & $\begin{array}{l}\text { - Aids neutrophil phagocytosis } \\
\text { - Increases IL-2 production }\end{array}$ & $\begin{array}{l}\text { - Increases T-cell proliferation } \\
\text { - Increases antibody production } \\
\text { - Improves cellular immunity by activating } \\
\text { cytokines and chemokines }\end{array}$ \\
\hline Selenium & $\begin{array}{l}\text { - Helps selenium-dependent enzymes (sialoproteins) to } \\
\text { resist oxidant production } \\
\text { •Supports function of NK cells and leukocytes } \\
\text { (macrophages, neutrophils, monocytes) }\end{array}$ & $\begin{array}{l}\text { - Increases antibody production } \\
\text { - Promotes T-cell proliferation and } \\
\text { differentiation }\end{array}$ \\
\hline
\end{tabular}


the omega-3 fatty acids have the capacity to boost immunity against viral infections. Similarly, it was also described the complex relationship between trace elements and viral infections, highlighting the immunomodulatory properties and antiviral activities of certain micronutrients such as iron, zinc, selenium, and copper. Apart from functioning as antioxidants, these trace elements were shown to inhibit viral replication in host cells.

Older adults, compared with younger populations, are more susceptible to COVID-19-like viral infections and their associated serious outcomes. This increased susceptibility is attributable to aging-associated physiological changes, a weakened immune response, malnutrition, and multimorbidities [40]. Prolonged hospitalization to ensure the stabilization and recovery of COVID-19 patients increases the risk of malnutrition and severe loss of lean body mass and muscle function. Nutritional screening and treatment of malnutrition in older patients is therefore mandated as part of COVID-19 patient care [41]. A recent crosssectional study from Wuhan, China, reported that 52.7 $\%$ of the 182 older adult patients with COVID-19 were malnourished, with the mean Mini Nutritional Assessment score being below 17 [42]. Advanced age is associated with a high risk of nutritional frailty, characterized by sudden weight loss, loss of lean body mass, and loss of physiological nutritional reserves. Nutritional frailty compromises an individual's ability to meet their nutritional needs and increases their susceptibility to disability [43]. The European Society for Clinical Nutrition and Metabolism [44] proposed several considerations for the nutritional care of older COVID-19 patients: nutritional screening; optimization

\section{REFERENCES}

1. Zhang L, Liu Y. Potential interventions for novel coronavirus in China: A systematic review. J Med Virol. 2020;92(5): 479-90. DOI:10.1002/jmv.25707

2. Schoeman D, Fielding BC. Coronavirus envelope protein: current knowledge. Virol J. 2019;16: 69 10.1186/ s12985-019-1182-0

3. Zhang N, Wang L, Deng $X$, et al. Recent advances in the detection of respiratory virus infection in humans. J Med Virol. 2020;92(4): 408-17. 10.1002/jmv.25674

4. Leung WK, To KF, Chan PK, Chan HL, Wu AK, Lee N, et al. Enteric involvement of severe acute respiratory syndromeassociated coronavirus infection. Gastroenterology. 2003;125: 1011-7. DOI: 10.1016/S0016-5085(03)01215-0

5. To KK, Tsang OT, Yip CCY, Chan KH, Wu TC, Chan JMC, et al. Consistent detection of 2019 novel coronavirus in saliva. Clin Infect Dis. 2020;71: 841-3. DOI: 10.1093/cid/ciaa149

6. Lu R, Zhao X, Li J, Niu P, Yang B, Wu H, et al. Genomic characterisation and epidemiology of 2019 novel coronavirus, implications for virus origins and receptor binding. Lancet. 2020;395: 565-74. DOI: 10.1016/S0140-6736(20)30251-8

7. Gu J, Han B, Wang J. COVID-19: gastrointestinal of nutritional status by dietary counseling; supplementation with essential vitamins and minerals, oral nutritional supplements, and enteral and parenteral nutritional support when nutritional needs are not met; and regular physical activity in quarantine. Adverse clinical outcomes of viral infections have been linked to low intakes of micronutrients. Thus, providing the RDA of vitamins $A, D, E, C, B_{6}$, and $B_{12}$ and iron, zinc, selenium, and omega-3 PUFAs to malnourished older adults may help prevent or treat adverse clinical outcomes of COVID-19.

\section{CONCLUSIONS}

1. The role of optimal nutrition for managing the current COVID-19 pandemic cannot be underestimated. Nutrition has a demonstrable role in the prevention and treatment of moderate to severe respiratory and nonrespiratory infections.

2. Adequate nutrition is even more essential for marginalized communities and in low- and middleincome countries, where deficiencies in key vitamins and minerals expose individuals to greater morbidity and mortality.

3. Low- and middle-income countries should strategize to ensure the population at large has access to optimal nutrition to boost the immune system and should provide specific supplementation for treatment of COVID-19 patients, especially those with severe disease.

4. Older adults represent a high-risk population and may be prioritized to receive care in nursing facilities and to receive specialized nutritional support to improve physical and mental outcomes of the COVID-19 pandemic.

manifestations and potential fecal-oral transmission. Gastroenterology. 2020;158: 1518-9. DOI: 10.1053/j. gastro.2020.02.054

8. Chau TN, Lee KC, Yao H, Tsang TY, Chow TC, Yeung YC, et al. SARS-associated viral hepatitis caused by a novel coronavirus, report of three cases. Hepatology. 2004;39: 302-10. DOI: 10.1002/hep.20111

9. Zhou P, Yang XL, Wang XG, Hu B, Zhang L, Zhang W, et al. A pneumonia outbreak associated with a new coronavirus of probable bat origin. Nature. 2020;579: 270-3. DOI: 10.1038/s41586-020-2012-7

10. Nasri H, Baradaran A, Shirzad H, Rafieian-Kopaei M. New concepts in nutraceuticals as alternative for pharmaceuticals. Int J Prev Med. 2014;5: 1487-99.

11. World Health Organisation. Nutrition. Nutrition advice for adults during the COVID-19 outbreak. Available from: http://www.emro.who.int/nutrition/nutrition-infocus/nutritionadvice-for-adults-during-the-covid-19-outbreak.html[last accessed 26 April 2020].

12. Childs CE, Calder PC, Miles EA. Diet and immune function. Nutrients. 2019;11: 1933.
$2(8), 2021$ 
13. Elmadfa I, Meyer AL. The role of the status of selected micronutrients in shaping the immune function. Endocr Metab Immune Disord Drug Targets. 2019;19: 1100-15.

14. Chaplin DD. Overview of the immune response. J Allergy Clin Immunol. 2010;125(2 suppl 2): S3-S23. DOI: 10.1016/j.jaci.2009.12.980

15. Romagnani S. T-cell subsets (Th1 versus Th2). Ann Allergy Asthma Immunol. 2000;85: 9-18.

16. Gombart AF, Pierre A, Maggini S. A review of micronutrients and the immune system-working in harmony to reduce the risk of infection. Nutrients. 2020;12: 236. DOI:10.3390/nu12010236

17. Chandra RK. Nutrition and the immune system from birth to old age. Eur J Clin Nutr. 2002;56(suppl 3): S73-S76.

18. Alpert PT. The role of vitamins and minerals on the immune system. Home Health Care Manag Pract. 2017;29: 199-202.

19. Milner JJ, Beck MA.. The impact of obesity on the immune response to infection. Proc Nutr Soc. 2012;71: 298-306

20. Diwakar BT, Finch ER, Liao C, et al.The role of selenoproteins in resolution of inflammation In: Hatfield DL, Schweizer U, Tsuji PA, Gladyshev VN, eds. Selenium: Its Molecular Biology and Role in Human Health. 4th ed.Springer International Publishing; 2016.

21. Haryanto B, Suksmasari $T$, Wintergerst $E$, et al. Multivitamin supplementation supports immune function and ameliorates conditions triggered by reduced air quality. Vitam Miner. 2015;4: 2-15. DOI:10.4172/2376-1318.1000128

22. McClung JP, Peterson DG. Trace elements and immune function In: Watson RR, Zibadi S, Preedy VR, Eds. Dietary Components and Immune Function. Humana Press; 2010: 253-62.

23. Saeed F, Nadeem M, Ahmed RS, et al.Studying the impact of nutritional immunology underlying the modulation of immune responses by nutritional compounds - a review. Food Agric Immunol. 2016;27: 205-29.

24. Weiss G. Iron and immunity: a double-edged sword. Eur J Clin Invest. 2002;32(suppl 1): 70-8.

25. Xu Y, Sherwood JA, Lackey KH, et al. The responses of immune cells to iron oxide nanoparticles. J Appl Toxicol. 2016;36: 543-53.

26. Wintergerst ES, Maggini S, Hornig DH.. Immuneenhancing role of vitamin $\mathrm{C}$ and zinc and effect on clinical conditions. Ann Nutr Metab. 2006;50: 85-94.

27. Maares M, Haase H.. Zinc and immunity: an essential interrelation. Arch Biochem Biophys. 2016;611: 58-65.

28. Maggini S, Wintergerst ES, Beveridge $S$, et al.Selected vitamins and trace elements support immune function by strengthening epithelial barriers and cellular and humoral immune responses. Br J Nutr. 2007;98(suppl 1): 29-S35.

29. Avery JC, Hoffmann PR.. Selenium, selenoproteins, and immunity. Nutrients. 2018;10: 1203. DOI:10.3390/ nu10091203

30. Ivory K, Prieto E, Spinks C, et al.Selenium supplementation has beneficial and detrimental effects on immunity to influenza vaccine in older adults. Clin Nutr. 2017;36: 407-15.

31. A phase 2 trial of high-dose ascorbate in glioblastoma multiforme. ClinicalTrials.gov identifier: NCT02344355.
https://clinicaltrials.gov/ct2/show/NCT02344355. Updated April 7, 2020. Accessed May 12, 2020.

32. Hydroxychloroquine and zinc with either azithromycin or doxycycline for treatment of COVID-19 in outpatient setting. ClinicalTrials.gov identifier: NCT04370782. https:// clinicaltrials.gov/ct2/show/NCT04370782?term=NCT0437 $0782 \& d r a w=2 \& r a n k=1$. Updated May 18, 2020. Accessed May 12, 2020.

33. TET2 mutations in myelodysplastic syndromes and acute myeloid leukemia with azacitidine + ascorbic acid. ClinicalTrials.gov identifier: NCT03397173. https:// clinicaltrials.gov/ct2/show/NCT03397173?term=NCT03397 $173 \& d r a w=2 \& r a n k=1$. Updated January 21, 2020. Accessed May 12, 2020.

34. Hagag AA, El Frargy MS, Houdeeb HA.. Therapeutic value of vitamin $D$ as an adjuvant therapy in neonates with sepsis [published online June 25, 2019]. Infect Disord Drug Targets. DOI:10.2174/1871526519666190626141859 [PubMed] [CrossRef] [Google Scholar]

35. Kim W-Y, Jo E-J, Eom JS, et al.Combined vitamin $C$, hydrocortisone, and thiamine therapy for patients with severe pneumonia who were admitted to the intensive care unit: propensity score-based analysis of a before-after cohort study. J Crit Care. 2018;47: 211-8. [PubMed] [Google Scholar]

36. Sánchez-Armendáriz K, García-Gil A, Romero CA, et al.Oral vitamin D3 $5000 \mathrm{IU} /$ day as an adjuvant in the treatment of atopic dermatitis: a randomized control trial. Int J Dermatol. 2018;57: 1516-20. [PubMed] [Google Scholar]

37. Gonçalves D, Lima C, Ferreira P, et al.Orange juice as dietary source of antioxidants for patients with hepatitis C under antiviral therapy. Food Nutr Res. 2017;61: 1296675. DOI:10.1080/16546628.2017.1296675 [PMC free article] [PubMed] [CrossRef] [Google Scholar]

38. Bhattacharjee A, Basu A, Biswas J, et al. Chemoprotective and chemosensitizing properties of selenium nanoparticle (Nano-Se) during adjuvant therapy with cyclophosphamide in tumor-bearing mice. Mol Cell Biochem. 2017;424: 13-33. [PubMed] [Google Scholar]

39. Kaya H, Koç AK, Sayın i, et al.Vitamins A, C, and $E$ and selenium in the treatment of idiopathic sudden sensorineural hearing loss. Eur Arch Otorhinolaryngol. 2015;272: 1119-25. [PubMed] [Google Scholar]

40. Zhou F, Yu T, Du R, et al. Clinical course and risk factors for mortality of adult inpatients with COVID-19 in Wuhan, China: a retrospective cohort study. Lancet. 2020;395: 1054-62.

41. Barazzoni R, Bischoff SC, Breda J, et al.ESPEN expert statements and practical guidance for nutritional management of individuals with SARS-CoV-2 infection. Clin Nutr. 2020;39: P1631-8. DOI:10.1016/j.clnu.2020.03.022

42. Li T, Zhang Y, Gong C, et al.Prevalence of malnutrition and analysis of related factors in elderly patients with COVID-19 in Wuhan, China [published online April 22, 2020]. Eur J Clin Nutr. 2020;74: 871-5. DOI:10.1038/s41430-020-0642-3

43. Kinney JM. Nutritional frailty, sarcopenia and falls in the elderly. Curr Opin Clin Nutr Metab Care. 2004;7: 15-20

44. Barazzoni R, Bischoff SC, Breda J, et al.ESPEN expert statements and practical guidance for nutritional management of individuals with SARS-CoV-2 infection. Clin Nutr. 2020;39: P1631-8. DOI:10.1016/j.clnu.2020.03.022 